\title{
Screening of Wild and Cultivated Capsicum Germplasm Reveals New Sources of Verticillium Wilt Resistance
}

Suraj Gurung and Dylan P. G. Short, Department of Plant Pathology, University of California, Davis, c/o U.S. Agricultural Research Station, Salinas, CA 93905; Xiaoping Hu, State Key Laboratory of Crop Stress Biology for Arid Areas and College of Plant Protection, Northwest A\&F University, Yangling, Shaanxi, China; German V. Sandoya, The Genome Center and Department of Plant Sciences, University of California, Davis, Salinas, CA 93905; Ryan J. Hayes, USDA-ARS, Salinas, CA 93905; and Krishna V. Subbarao, Department of Plant Pathology, University of California, Davis, c/o U.S. Agricultural Research Station, Salinas 93905

\begin{abstract}
Gurung, S., Short, D. P. G., Hu, X., Sandoya, G. V., Hayes, R. J., and Subbarao, K. V. 2015. Screening of wild and cultivated Capsicum germplasm reveals new sources of Verticillium wilt resistance. Plant Dis. 99:1404-1409.

Verticillium wilt caused by Verticillium dahliae is an important soilborne disease of pepper (Capsicum species) worldwide. Most commercial pepper cultivars lack resistance to this pathogen. Our objective was to identify resistance to two $V$. dahliae isolates in wild and cultivated Capsicum accessions from the core collection of the National Plant Germplasm System of the USDA. Screening of 397 Capsicum accessions against two $V$. dahliae isolates (Vdca59 and $\mathrm{VdCf45}$ ) was performed in a greenhouse. Seventy-eight accessions selected from this screen were further evaluated in a follow-up experiment. In total, 21 (26.9\%) and 13 (16.6\%) Capsicum

accessions tested were resistant to Verticillium wilt when inoculated with V. dahliae isolates VdCa59 and VdCf45, respectively. Eight accessions (Grif 9073, PI 281396, PI 281397, PI 438666, PI 439292, PI 439297, PI 555616, and PI 594125) were resistant to Verticillium wilt against both $V$. dahliae isolates. On the basis of Germplasm Resources Information Network data, two of the Capsicum annиum accessions (Grif 9073 and PI 439297) were also resistant to Phytophthora root rot disease. These sources of multiple disease resistance will be useful to pepper breeding programs.
\end{abstract}

Cultivated peppers $(2 n=2 x=24)$ are a globally important crop encompassing bell, chili (spicy), and other types of peppers, all belonging within the genus Capsicum and originating in the American tropics (Pickersgill 1997). Considerable diversity exists within cultivated and wild Capsicum, not only for agronomic characters such as fruit color, shape, and size, but for pest and disease resistance (Pickersgill 1997; Walsh and Hoot 2001). Five cultivated species are known. Capsicum annuum L., C. frutescens L., and C. chinense Jacq., are widely grown throughout the world, while production of C. baccatum L., C. baccatum var. pendulum Willd., and C. pubescens Ruiz and Pav. occurs mostly within South America. More than 20 wild Capsicum species have been described, including C. annuum var. glabriusculum (Dun.) Heiser \& Pickersgill and C. baccatum var. baccatum Eshbaugh, which are closely related to cultivated peppers (Nicolaï et al. 2013). Natural interspecific hybridization can occur between species and is hypothesized to have contributed to the diversity observed in present-day peppers (Perry et al. 2007). California leads the United States in the production of peppers. In 2012, pepper production experienced a 30\% increase from the previous year; bell and chili pepper crops were valued at approximately $\$ 281$ and $\$ 100$ million dollars, respectively (USDA-NASS 2013).

Verticillium wilt of peppers, caused by the fungus Verticillium dahliae, is a serious threat to pepper production worldwide (Evans and McKeen 1975; Douira et al. 1995; García-Mina et al. 1996; Tsror et al. 1998; Pegg and Brady 2002; Pernezny et al. 2003; Goicoechea 2006). Verticillium wilt of pepper (C. annum) in the United States

Corresponding author: Krishna V. Subbarao;

E-mail: kvsubbarao@ucdavis.edu.

First two authors contributed equally to this study.

*The $\boldsymbol{e}$-Xtra logo stands for "electronic extra" and indicates that one supplementary table is published online.

Accepted for publication 18 April 2015.

http://dx.doi.org/10.1094/PDIS-01-15-0113-RE

(C) 2015 The American Phytopathological Society was first reported in 1937 from pepper fields in California, where the disease resulted in more than 20\% yield loss (Rudolph and Snyder 1937). Since then, Verticillium wilt in pepper has been observed and described in different parts of the world (González-Salán and Bosland 1992; Douira et al. 1995; Tsror et al. 1998; Bhat et al. 2003; Goicoechea 2006). Verticillium dahliae penetrates pepper plants through wounded roots and spreads systemically through the xylem, and as the disease symptoms develop acropetally, the vascular tissue turns a characteristic brownish-black. As the disease becomes severe, stunting, epinasty, foliar chlorosis, progressive necrosis, and leaf abscission are also clearly visible (Bhat et al. 2003; Goicoechea 2006). These symptoms lead to decreased fruit yield and quality.

Cultural control methods for Verticillium wilt are expensive or have limited feasibility because $V$. dahliae microsclerotia can survive in the soil for more than 14 years (Wilhelm 1955; Pegg and Brady 2002), and in addition, V. dahliae from several hosts including pepper are cross-pathogenic on several crops grown in rotation (Tsror et al. 1998; Bhat et al. 2003; Sanogo et al. 2009). Methyl bromide $(\mathrm{MeBr})$ was the most effective soil fumigant to reduce populations of several soilborne pathogens including $V$. dahliae, but $\mathrm{MeBr}$ has now been phased out as part of the Montreal Protocol to eliminate ozone depleting compounds in industry and agriculture (Subbarao 2002). Currently, alternative soil fumigants that are as biocidal and cost-effective as $\mathrm{MeBr}$ do not exist (Rekanovic et al. 2007), while the environmental persistence and adverse effects on human health of other chemicals (chloropicrin) remain an issue. Thus, host resistance to Verticillium wilt represents the best long-term strategy to manage this disease (Hayes et al. 2007).

A few sources of peppers with partial resistance against Verticillium wilt have been identified either from field screening using natural soil inoculum or greenhouse experiments using conidial and microsclerotial inoculum (Fiume et al. 1982; Pesti et al. 1985; Palloix et al. 1990; González-Salán and Bosland 1992). Although field testing seems practical for selecting Verticillium wilt-resistant germplasm and for breeding resistance against Verticillium wilt, the resistance observed under field conditions proved to be susceptible under greenhouse conditions with conidial inoculum (Palloix et al. 1990). Field testing requires significant time and space, and with disease escape resulting from variation in pathogen distribution and other environmental 
conditions, obtaining accurate response of germplasm lines to the pathogen can be a problem (Hayes et al. 2007). It has also been historically difficult to find a field with a history of consistent Verticillium wilt, because farmers often decide to fumigate their fields as soon as they observe Verticillium wilt. For these reasons, identification of potential sources of resistance under greenhouse conditions is an attractive option.

Complete and partial resistance to Verticillium wilt has been described in numerous crop species (Pegg and Brady, 2002). In tomato, cultivars with the $V e 1$ gene exhibit high-level resistance to race $1 \mathrm{~V}$. dahliae isolates, which carry the Avel effector (de Jonge et al. 2012). Race $2 \mathrm{~V}$. dahliae isolates that lack Avel cause disease on tomato cultivars possessing $\mathrm{Vel}$. Some lettuce cultivars exhibit complete resistance to race 1 isolates (Hayes et al. 2007; Maruthachalam et al. 2010), while only partial resistance to race 2 has been identified (Hayes et al. 2011). Limited sources of resistance are available against Verticillium wilt in peppers, and finding additional sources is very difficult and challenging (Woolliams et al. 1962). Previously, most of the 456 Capsicum accessions tested against $V$. dahliae were susceptible and only a few lines showed even a low level of resistance (Woolliams et al. 1962). Similarly, a screen of 125 Capsicum accessions failed to find accessions with desirable levels of resistance to Verticillium wilt, although three accessions showed partial resistance (González-Salán and Bosland 1992). Since these studies, additional plant introductions have become available through the United States Department of Agriculture, National Plant Germplasm System (NPGS), which, to our knowledge, have not been screened for Verticillium wilt resistance.

Despite the reports of tolerant pepper cultivars (Padrón and Yolo Wonder), resistance has neither been detected nor well characterized

Table 1. Capsicum species and collection locations of 397 accessions evaluated for resistance to Verticillium dahliae

\begin{tabular}{|c|c|}
\hline Capsicum species and collection location & Number of accessions \\
\hline \multicolumn{2}{|l|}{ C. annuum } \\
\hline Costa Rica & 43 \\
\hline Guatemala & 12 \\
\hline India & 2 \\
\hline Mexico & 241 \\
\hline Nicaragua & 1 \\
\hline Spain & 1 \\
\hline Turkey & 3 \\
\hline \multicolumn{2}{|l|}{ C. annuum var. glabriusculum } \\
\hline Costa Rica & 1 \\
\hline Mexico & 28 \\
\hline unknown & 1 \\
\hline \multicolumn{2}{|l|}{ C. baccatum $\mathrm{L}$. } \\
\hline Chile & 1 \\
\hline Costa Rica & 1 \\
\hline \multicolumn{2}{|l|}{ C. baccatum var. baccatum } \\
\hline Peru & 1 \\
\hline \multicolumn{2}{|l|}{ C. baccatum var. pendulum } \\
\hline Bolivia & 1 \\
\hline Brazil & 1 \\
\hline Bulgeria & 1 \\
\hline Guatemala & 1 \\
\hline Peru & 3 \\
\hline \multicolumn{2}{|l|}{ C. chinense } \\
\hline Costa Rica & 3 \\
\hline Mexico & 3 \\
\hline \multicolumn{2}{|l|}{ C. frutescens } \\
\hline Costa Rica & 15 \\
\hline Guatemala & 1 \\
\hline Mexico & 13 \\
\hline \multicolumn{2}{|l|}{ Unknown Capsicum species } \\
\hline Costa Rica & 2 \\
\hline Mexico & 3 \\
\hline USA & 1 \\
\hline Unknown & 13 \\
\hline
\end{tabular}

in the Capsicum-V. dahliae system (Pomar et al. 2004). Commercial pepper cultivars showing complete resistance to Verticillium wilt are currently unavailable (Pernezny et al. 2003). Thus, searching for novel sources of high resistance to Verticillium wilt is a priority. The NPGS has the largest collection of worldwide pepper accessions. Candole et al. (2010) and Yanar and Miller (2003) identified several $C$. annuum accessions with resistance to multiple isolates of Phytophthora capsici and Sclerotinia sclerotiorum. The pepper accessions at the NPGS may also contain sources of $V$. dahliae resistance. The objective of this study was to identify pepper germplasm with resistance to Verticillium wilt from 397 accessions collected from Mexico (the center of origin for pepper) and a few other Asian, European, and South American countries.

\section{Materials and Methods}

Pepper germplasm and plant growth conditions. Pepper seeds from 397 germplasm accessions were received from the NPGS (Table 1). These included accessions described as C. annuum, C. annuum var. glabriusculum, C. baccatum, C. baccatum var. baccatum, C. baccatum var. pendulum, C. chinese, C. frutescens, and "Capsicum species." Countries of origin of all 397 accessions are shown in Table 1.

Seeds were sown in 200-well plug trays containing Sunshine plug Mix No. 4 (SunGro Horticulture, AgWam, MA) and watered with fine mist under ambient light conditions in a greenhouse (Salinas, CA). Fan-forced radiant heat was turned on when temperature dropped below $18^{\circ} \mathrm{C}$ and an automatic exhaust fan with evaporative cooling was turned on when temperature exceeded $24^{\circ} \mathrm{C}$.

Fungal isolates and inoculation. Two isolates of $V$. dahliae, $\mathrm{VdCa} 59$ and $\mathrm{VdCf} 45$, originally isolated from $C$. annuum and $C$. frutescens in California production fields, respectively, were used in this study based on previous virulence assays (Bhat and Subbarao 1999; Bhat et al. 2003). Prior to greenhouse experiments, cultures of VdCa59 and $\mathrm{VdCf} 45$ were grown for DNA extraction as previously described (Gurung et al. 2014) and verified as V. dahliae sensu stricto (Inderbitzin et al. 2011), and as race 2 (lacking the Avel effector) following previously described polymerase chain reaction (PCR) and gel electrophoresis (Inderbitzin et al. 2013; Short et al. 2014). Briefly, isolates were single-spored on potato dextrose agar (PDA), transferred into conical flasks containing potato dextrose broth (PDB), and incubated on laboratory benches $\left(23 \pm 1^{\circ} \mathrm{C}\right)$. After 1 week, mycelia were harvested from PDB, rinsed thoroughly with double-sterilized distilled water and dried using paper towels. Mycelia were then lyophilized and ground to fine powder using a high-speed mixer mill (Model MM301; Retsch Inc., Newtown, PA). Genomic DNA was extracted using a FastDNA Kit (MP Biomedicals, Santa Ana, CA). Published PCR protocols (Inderbitzin et al. 2011; Short et al. 2014) were used to verify species and race of VdCa59 and VdCf45.

Pepper seedlings were inoculated at 2 weeks after emergence by saturating the soil in each well of the plug trays with 5 to $10 \mathrm{ml}$ of spore suspension $\left(1 \times 10^{8}\right.$ conidia/ml $)$. Two additional inoculations with each isolate were done 1 and 2 weeks after the first inoculation. Plants were then transferred into 0.5-liter foam cups filled with a pasteurized sand/potting soil mixture $(2: 1 \mathrm{vol} / \mathrm{vol})$. Prior to transplanting pepper seedlings, a single $1-\mathrm{cm}^{2}$ PDA plug of VdCa59 and VdCf45 was placed at the bottom of the transplant cavity in the pot. Two additional inoculations with conidial spore suspension were done 1 and 2 weeks after transplanting. Peppers plants were watered regularly and fertilized with MiracleGro approximately once every 2 to

Table 2. Analysis of variance of $80(78+2$ controls) pepper plant introductions (PIs) tested with isolates $\mathrm{VdCa} 59$ and $\mathrm{VdCf} 45$ of Verticillium dahliae

\begin{tabular}{lccc}
\hline Source & Degrees of freedom & $\boldsymbol{P}>$ F VdCa59 $^{\mathbf{b}}$ & $\boldsymbol{P}>$ F VdCf45 \\
\hline Blocks & 15 & 0.9363 & 0.5477 \\
Controls $^{\text {a }}$ & 1 & $<0.0001$ & $<0.0001$ \\
New cultivars & 77 & $<0.0001$ & $<0.0001$ \\
\hline
\end{tabular}

a Controls used are PI 215699 (partially resistant) and cv. California Wonder (susceptible) (Bhat et al. 2003).

b Probabilities associated with the sources of variation. 
3 weeks (The Scotts Company, Marysville, $\mathrm{OH}$ ). Control plants were treated with sterilized distilled water. A total of 397 accessions were screened for Verticillium wilt disease severity and plant height in a nonreplicated experiment. Each cultivar was screened once against each isolate with uninoculated plants serving as controls. Ten plants per accession per isolate were screened, and the inoculated and uninoculated plants were arranged on greenhouse benches in a completely randomized design.

A total of 78 accessions were selected based on the results from the initial screen described above and were evaluated in a follow-up experiment. Because the amount of seed of these accessions was limited, the experiment was arranged in an augmented randomized complete block design (ARCBD). The experiment consisted of 16 blocks where the accessions were replicated only once. The partially resistant Plant Introduction (PI 215699) (González-Salán and Bosland 1992) and the susceptible (California Wonder) (Bhat et al. 2003) were used as controls and replicated in each block. Each plot consisted of 10 plants and the average disease score per plot were used for the analysis. The experiment was conducted two times.

Disease severity rating. Plants were incubated on greenhouse benches for 8 weeks after the final inoculation, uprooted, and washed free of soil. Plant height was measured from the crown to the tip of the leaves with a meter stick, and the roots were longitudinally cut to evaluate Verticillium wilt severity. The extent of root and crown discoloration in inoculated and control plants was rated on a 0 -to-5 scale, where $0=$ no vascular discoloration; $1=1$ to $25 \%$ of the vascular tissue exhibiting discoloration; $2=26$ to $50 \%, 3=51$ to $75 \%$, and $4=76$ to $100 \%$ discoloration in the absence of foliar symptoms; and $5=100 \%$ discoloration and the presence of foliar symptoms typical of Verticillium wilt (Bhat et al. 2003; Vallad et al. 2006). In the laboratory, symptomatic roots were cleaned using distilled water and $5 \%$ bleach, dissected, and plated on NP-10 medium (Kabir et al. 2004; Perry et al. 2007). After 10 days incubation at ambient temperature, plates were examined under a dissecting microscope for the

Table 3. Least squares means of 78 pepper (Capsicum spp.) plant introductions (PIs) screened for Verticillium wilt with two isolates of Verticillium dahliae in Salinas, California in 2014

\begin{tabular}{|c|c|c|c|c|c|c|c|}
\hline \multirow[b]{2}{*}{ Plant introduction } & \multirow[b]{2}{*}{ Capsicum species (origin)a } & \multicolumn{3}{|c|}{ VdCa59 } & \multicolumn{3}{|c|}{ VdCf45 } \\
\hline & & $\mathrm{DS}^{\mathrm{d}}$ & $P$ resistant ${ }^{b}$ & $P$ susceptible ${ }^{c}$ & DS & $P$ resistant ${ }^{b}$ & $P$ susceptible ${ }^{c}$ \\
\hline Grif 9120 & C. аппиит (CR) & 3.0 & $\mathrm{~ns}^{\mathrm{e}}$ & $\mathrm{ns}$ & 4.0 & $\mathrm{~ns}$ & $\mathrm{~ns}$ \\
\hline Grif 9175 & C. аппиит (CR) & 0.4 & $\mathrm{~ns}$ & 0.0001 & 4.3 & ns & ns \\
\hline PI200726 & C. аппиит (GU) & 3.3 & ns & ns & 4.0 & ns & ns \\
\hline PI164847 & C. аппиит (IN) & 4.3 & $\mathrm{~ns}$ & ns & 4.7 & 0.0263 & ns \\
\hline Grif 12452 & C. аппиит (MX) & 4.4 & $\mathrm{~ns}$ & $\mathrm{~ns}$ & 3.7 & ns & $\mathrm{ns}$ \\
\hline Grif 9073 & C. аппиит (MX) & 1.1 & ns & 0.0001 & 0.9 & ns & 0.0001 \\
\hline Grif 9109 & C. аппиит (MX) & 1.4 & ns & 0.0001 & 2.8 & $\mathrm{~ns}$ & 0.0001 \\
\hline PI188472 & C. аппиит (MX) & 3.8 & ns & ns & 3.9 & ns & $\mathrm{ns}$ \\
\hline PI201232 & C. аппиит (MX) & 4.6 & ns & ns & 4.3 & ns & ns \\
\hline PI201233 & C. аппиит (MX) & 2.1 & $\mathrm{~ns}$ & 0.0196 & 4.4 & ns & ns \\
\hline PI201234 & C. аппиит (MX) & 3.2 & $\mathrm{~ns}$ & $\mathrm{~ns}$ & 4.4 & ns & ns \\
\hline PI201240 & C. аппиит (MX) & 3.4 & ns & ns & 5.0 & 0.0012 & $\mathrm{~ns}$ \\
\hline PI201241 & C. аппиит (MX) & 0.3 & $\mathrm{~ns}$ & 0.0001 & 4.2 & ns & $\mathrm{ns}$ \\
\hline PI224438 & C. аппиит (MX) & 1.3 & ns & 0.0001 & 2.7 & ns & 0.0001 \\
\hline PI266039 & C. аппиит (MX) & 3.3 & ns & ns & 3.7 & ns & ns \\
\hline PI267733 & C. аппиит (MX) & 1.4 & $\mathrm{~ns}$ & 0.0001 & 4.0 & ns & ns \\
\hline PI267735 & C. аппиит (MX) & 2.6 & ns & ns & 4.3 & ns & $\mathrm{ns}$ \\
\hline PI268101 & C. аппиит (MX) & 2.0 & $\mathrm{~ns}$ & 0.0092 & 4.8 & 0.0101 & $\mathrm{~ns}$ \\
\hline PI281359 & C. аппиит (MX) & 3.8 & ns & $\mathrm{ns}$ & 3.8 & $\mathrm{~ns}$ & $\mathrm{~ns}$ \\
\hline PI281376 & C. аппиит (MX) & 0.7 & ns & 0.0001 & 3.8 & ns & $\mathrm{ns}$ \\
\hline PI438621 & C. аппиит (MX) & 2.4 & $\mathrm{~ns}$ & ns & 3.8 & ns & $\mathrm{ns}$ \\
\hline PI438646 & C. аппиит (MX) & 3.3 & $\mathrm{~ns}$ & ns & 3.8 & $\mathrm{~ns}$ & $\mathrm{~ns}$ \\
\hline PI438657 & C. аппиит (MX) & 2.9 & ns & ns & 3.6 & ns & ns \\
\hline PI438664 & C. аппиит (MX) & 3.8 & $\mathrm{~ns}$ & ns & 3.8 & ns & $\mathrm{ns}$ \\
\hline PI438666 & C. аппиит (MX) & 0.3 & $\mathrm{~ns}$ & 0.0001 & 1.0 & ns & 0.0001 \\
\hline PI439267 & C. аппиит (MX) & 4.3 & ns & $\mathrm{ns}$ & 3.3 & ns & 0.0263 \\
\hline PI439268 & C. аппиит (MX) & 2.9 & $\mathrm{~ns}$ & ns & 2.9 & ns & 0.0004 \\
\hline PI439269 & C. аппиит (MX) & 4.1 & $\mathrm{~ns}$ & ns & 4.0 & $\mathrm{~ns}$ & $\mathrm{~ns}$ \\
\hline PI439271 & C. аппиит (MX) & 4.0 & ns & ns & 4.3 & ns & $\mathrm{ns}$ \\
\hline PI439273 & C. аппиит (MX) & 3.0 & ns & ns & 4.7 & 0.0263 & $\mathrm{~ns}$ \\
\hline PI439274 & C. аппиит (MX) & 2.1 & $\mathrm{~ns}$ & 0.0196 & 2.3 & $\mathrm{~ns}$ & 0.0001 \\
\hline PI439292 & C. аппиит (MX) & 0.2 & ns & 0.0001 & 1.3 & ns & 0.0001 \\
\hline PI439297 & C. аппиит (MX) & 1.1 & $\mathrm{~ns}$ & 0.0001 & 0.9 & ns & 0.0001 \\
\hline PI439299 & C. аппиит (MX) & 3.0 & $\mathrm{~ns}$ & $\mathrm{~ns}$ & 3.4 & ns & $\mathrm{ns}$ \\
\hline PI439301 & C. аппиит (MX) & 4.1 & ns & ns & 2.4 & ns & 0.0001 \\
\hline PI439303 & C. аппиит (MX) & 2.6 & $\mathrm{~ns}$ & ns & 2.0 & ns & 0.0001 \\
\hline PI439304 & C. аппиит (MX) & 0.3 & ns & 0.0001 & 3.8 & ns & ns \\
\hline PI439305 & C. аппиит (MX) & 3.6 & ns & $\mathrm{ns}$ & 3.4 & ns & ns \\
\hline
\end{tabular}

${ }^{a} \mathrm{MX}=$ Mexico, $\mathrm{CR}=$ Costa Rica, $\mathrm{PE}=$ Peru, GU = Guatemala, $\mathrm{BR}=$ Brazil, $\mathrm{BO}=$ Bolivia, $\mathrm{TU}=$ Turkey, $\mathrm{SP}=\mathrm{Spain}$, and $\mathrm{IN}=\mathrm{India}$.

b $P$ values from the Dunnett test when the new accessions were compared with the resistant PI 215699.

c $P$ values from the Dunnett test when the new accessions were compared with the susceptible cv. California wonder.

d DS = Disease severity was assessed based on the extent of root and crown discoloration on a 0 to 5 scale, where $0=$ no vascular discoloration; $1=1$ to $25 \%$ of the vascular tissue exhibiting discoloration; $2=26$ to $50 \%, 3=51$ to $75 \%$, and $4=76$ to $100 \%$ discoloration in the absence of foliar symptoms; and $5=100 \%$ discoloration and the presence of foliar symptoms typical of Verticillium wilt (Bhat et al. 2003; Vallad et al. 2006).

e ns $=$ Nonsignificant at $P<0.05$. 
presence of verticillate conidiophores and microsclerotia typical of V. dahliae (Inderbitzin et al. 2011).

Data analysis. Analysis of variance of the ranked means was performed using the data from the initial screen of 397 accession in PROC MIXED of SAS (SAS Institute Inc., Cary, NC) considering plants as biological replicates. The Relative Marginal Effects (RME) values were calculated using the LD_CI macro written in PROC IML of SAS, and the experiment was considered a randomized design.

An analysis of variance (ANOVA) was calculated individually for each isolate in PROC MIXED of SAS using the data collected from the ARCBD of 78 accessions. In the ANOVA, the cultivars were considered fixed effects and blocks were considered random effects. Pairwise comparisons of all cultivars were made using the TukeyKramer test at a probability of $95 \%$. The nonreplicated entries were compared with the partially resistant and/or the susceptible control using the Dunnett test at a probability of $95 \%$.

\section{Results}

Initial screening of pepper accessions with two isolates of V. dahliae. A total of 397 pepper plant introductions were assessed for their response against two race 2 isolates of $V$. dahliae. Besides wilting, a reduction in plant height was observed. The reduction in plant height of the PIs with isolate VdCA59 varied from 5 to $88 \%$ and from to 10 to $89 \%$ with isolate $\mathrm{VdCf} 45$ (Supplementary Table 1). Disease severity ranged from 0 to 4.9 with isolate $\mathrm{VdCa} 59$ and from 0 to 5 with VdVd45 (Supplementary Table 1). Using this data, accessions were selected for additional experiments based on low disease severity and height reduction to one or both $V$. dahliae isolates compared with susceptible cv. California Wonder.

Second screening of pepper accessions with two isolates of V. dahliae. A second screening with 78 accessions that had a lower disease severity in the preliminary screening was performed using an augmented design and with the partially resistant PI 215699 and the susceptible cv. California Wonder. Both experiments showed significant differences for the pepper cultivars tested $(P \leq 0.0001)$; blocks showed no significant differences and the cultivars used as controls also showed significant differences $(P \leq 0.001)$ (Table 2). Genetic variation for disease severity was detected in the PIs tested with isolate $\mathrm{VdCa} 59$. Two hundred and forty nine pairwise comparisons were significant, according to the Tukey-Kramer test (data not shown). Higher genetic variation was detected when the PIs were

Table 3. (continued from preceding page)

\begin{tabular}{|c|c|c|c|c|c|c|c|}
\hline \multirow[b]{2}{*}{ Plant introduction } & \multirow[b]{2}{*}{ Capsicum species (origin) ${ }^{\mathbf{a}}$} & \multicolumn{3}{|c|}{ VdCa59 } & \multicolumn{3}{|c|}{ VdCf45 } \\
\hline & & $\mathbf{D S}^{\mathbf{d}}$ & $P$ resistant ${ }^{b}$ & $P$ susceptible ${ }^{c}$ & DS & $P$ resistant ${ }^{\mathrm{b}}$ & $P$ susceptible $^{\mathrm{c}}$ \\
\hline PI439306 & C. аппиит (MX) & 4.4 & $\mathrm{~ns}$ & ns & 5.0 & 0.0012 & ns \\
\hline PI439307 & C. аппиит (MX) & 4.0 & ns & ns & 2.9 & ns & 0.0004 \\
\hline PI439310 & C. аппиит (MX) & 2.8 & $\mathrm{~ns}$ & ns & 4.0 & ns & ns \\
\hline PI439311 & C. аппиит (MX) & 4.0 & ns & ns & 3.6 & ns & ns \\
\hline PI439313 & C. аппиит (MX) & 2.9 & ns & ns & 5.0 & 0.0012 & ns \\
\hline PI511882 & C. аппиит (MX) & 2.4 & ns & ns & 3.4 & $\mathrm{~ns}$ & ns \\
\hline PI555625 & C. аппиит (MX) & 2.8 & ns & ns & 3.0 & ns & 0.0012 \\
\hline PI593503 & C. аппиит (MX) & 3.2 & ns & ns & 2.4 & ns & 0.0001 \\
\hline PI593538 & C. аппиит (MX) & 2.1 & ns & 0.0196 & 3.8 & $\mathrm{~ns}$ & $\mathrm{~ns}$ \\
\hline PI593539 & C. аппиит (MX) & 4.1 & ns & ns & 2.3 & ns & 0.0001 \\
\hline PI593540 & C. аппиит (MX) & 3.7 & ns & ns & 0.8 & ns & 0.0001 \\
\hline PI594121 & C. аппиит (MX) & 2.8 & ns & ns & 1.8 & $\mathrm{~ns}$ & 0.0001 \\
\hline PI594125 & C. аппиит (MX) & 1.8 & ns & 0.0018 & 0.6 & ns & 0.0001 \\
\hline PI164558 & C. аппиит (SP) & 2.2 & ns & 0.04 & 4.7 & 0.0263 & ns \\
\hline PI169135 & C. аппиит (TU) & 3.8 & $\mathrm{~ns}$ & ns & 4.9 & 0.0036 & ns \\
\hline PI169136 & C. аппиит (TU) & 2.9 & ns & ns & 4.0 & ns & ns \\
\hline PI381626 & C. аппиит var. glabriusculum (MX) & 3.9 & ns & ns & 3.4 & ns & $\mathrm{ns}$ \\
\hline PI593577 & C. аппиит var. glabriusculum (MX) & 4.4 & $\mathrm{~ns}$ & ns & 0.6 & $\mathrm{~ns}$ & 0.0001 \\
\hline PI439373 & C. baccatum $(\mathrm{CR})$ & 2.8 & ns & ns & 2.0 & ns & 0.0001 \\
\hline PI215699 & C. baccatum var. baccatum (PE) & 2.1 & ns & 0.0001 & 4.7 & 0.0263 & $\mathrm{~ns}$ \\
\hline PI260572 & C. baccatum var. pendulum (BO) & 2.8 & ns & $\mathrm{ns}$ & 5.0 & 0.0012 & $\mathrm{~ns}$ \\
\hline PI260593 & C. baccatum var. pendulum (BR) & 3.3 & ns & ns & 2.9 & ns & 0.0004 \\
\hline PI267729 & C. baccatum var. pendulum (GU) & 3.4 & $\mathrm{~ns}$ & ns & 3.1 & $\mathrm{~ns}$ & 0.0036 \\
\hline PI215741 & C. baccatum var. pendulum (PE) & 2.0 & ns & 0.0092 & 3.6 & $\mathrm{~ns}$ & $\mathrm{~ns}$ \\
\hline PI260549 & C. baccatum var. pendulum (PE) & 2.3 & ns & ns & 5.0 & 0.0012 & $\mathrm{~ns}$ \\
\hline PI260550 & C. baccatum var. pendulum (PE) & 2.3 & ns & ns & 3.4 & $\mathrm{~ns}$ & $\mathrm{~ns}$ \\
\hline Grif 9111 & C. chinense (MX) & 3.3 & ns & ns & 3.4 & $\mathrm{~ns}$ & $\mathrm{~ns}$ \\
\hline Grif 9118 & C. frutescens (CR) & 3.1 & $\mathrm{~ns}$ & ns & 5.0 & 0.0012 & ns \\
\hline Grif 9322 & C. frutescens (CR) & 1.9 & ns & 0.0041 & 4.9 & 0.0036 & ns \\
\hline Grif 9336 & C. frutescens (CR) & 0.4 & ns & 0.0001 & 3.8 & ns & ns \\
\hline Grif 9110 & C. frutescens (MX) & 1.9 & ns & 0.0041 & 4.6 & ns & ns \\
\hline PI188477 & C. frutescens (MX) & 3.1 & $\mathrm{~ns}$ & ns & 3.9 & $\mathrm{~ns}$ & $\mathrm{~ns}$ \\
\hline PI281396 & C. frutescens (MX) & 0.1 & ns & 0.0001 & 1.8 & ns & 0.0001 \\
\hline PI281397 & C. frutescens (MX) & 1.0 & ns & 0.0001 & 0.3 & ns & 0.0001 \\
\hline PI438667 & C. frutescens (MX) & 1.8 & $\mathrm{~ns}$ & 0.0018 & 3.4 & $\mathrm{~ns}$ & ns \\
\hline PI439511 & C. frutescens (MX) & 3.8 & ns & ns & 3.4 & ns & $\mathrm{ns}$ \\
\hline PI439512 & C. frutescens (MX) & 2.3 & $\mathrm{~ns}$ & ns & 2.9 & ns & 0.0004 \\
\hline Grif 9127 & Capsicum species (CR) & 4.1 & ns & ns & 3.8 & ns & ns \\
\hline PI555614 & Capsicum species (MX) & 3.9 & ns & ns & 2.9 & ns & 0.0004 \\
\hline PI555616 & Capsicum species (MX) & 0.1 & $\mathrm{~ns}$ & 0.0001 & 1.4 & ns & 0.0001 \\
\hline PI215699 & resistant control & 2.9 & ns & $\mathrm{ns}$ & 3.2 & ns & 0.0001 \\
\hline California Wonder & susceptible control & 4.0 & ns & ns & 4.8 & 0.0001 & $\mathrm{~ns}$ \\
\hline Overall Mean & & 2.7 & & & 3.4 & & \\
\hline
\end{tabular}


inoculated with isolate VdCf45, as 547 pairwise comparisons were significant (data not shown). The 78 accessions were also compared with the partial resistant (PI 215699) and susceptible cv. California Wonder controls using the Dunnett test. None of the accessions were significantly better or worse than partially resistant PI 215699 but 26 PIs were significantly better than $\mathrm{cv}$. California Wonder against isolate VdCa59. In the experiments with VdCf45, 14 PIs were significantly worse than the partial resistant PI 215699 and 28 PIs were more resistant compared with cv. California Wonder (Table 3). Plant Introductions 281396, 281397, 438666, 439292, 439297, 555616, 594125, and Grif 9073 possess acceptable levels of resistance to both VdCa59 and VdCf45, with disease severity scores of $\leq 2$. The accessions 201241, 281376, 439304, Grif 9175, and Grif 9336 were resistant against VdCa59 but were susceptible against VdCf45. Similarly, PIs 593540 and 593577 were resistant to VdCa59 but susceptible to VdCf45 (Table 3).

The cultivars that served as resistant and susceptible controls had similar disease scores against both isolates. The partially resistant PI 215699 had an average disease score of 2.9 against VdCa59 and a 3.2 against VdCf45. The susceptible cv. California Wonder had average disease scores of 4.0 and 4.8 against $\mathrm{VdCa} 59$ and $\mathrm{VdCf} 45$, respectively (Table 2).

\section{Discussion}

Current management strategies to reduce the impact of Verticillium wilt in commercial pepper production include soil fumigation and planting resistant cultivars. One of the most effective soil fumigants, $\mathrm{MeBr}$, will completely phase out in 2015, and other fumigants as effective as $\mathrm{MeBr}$ are currently unavailable (Subbarao 2002). As a result, it is likely that many crops grown in Coastal California, including pepper, will face greater disease pressure from soilborne pathogens such as $V$. dahliae. However, using soil fumigants to manage Verticillium wilt is not always practical or the best option due to higher costs and their potential effects on environmental and human health.

Therefore, it is imperative to identify and develop resistant pepper varieties for managing $V$. dahliae. The Yucatán Peninsula of southeastern Mexico is reported to be one of the potential centers of origin for domesticated Capsicum species (Aguilar-Melendez et al. 2009). Plant centers of origin often possess the highest genetic diversity and are considered potential sources of resistant materials against plant diseases. For this reason, in this study, most of the Capsicum accessions screened originated from Mexico and a few other Asian, European, and South American countries. Capsicum accessions with high levels of resistance to two virulent isolates of $V$. dahliae were identified, and these could be useful sources of resistance for pepper breeding programs.

Identifying resistance against pathogens is best accomplished under field conditions. However, pepper is often infected by multiple soilborne pathogens like $V$. dahliae, $P$. capsici, and others, making it very difficult to screen or work against a single pathogen under field conditions. In addition, it is very difficult to find a field with uniform disease pressure against soilborne pathogens. Therefore, we performed experiments under controlled-environment conditions, and used stringent criteria such as multiple inoculations with relatively high inoculum concentration $\left(1 \times 10^{8}\right.$ conidia/ml $)$ to minimize chances of disease escape. The very high incidence of wilt and root discoloration in the susceptible cv. California Wonder and most of the accessions tested demonstrated that the two isolates used in this study were highly virulent and that the screening technique used was consistently effective. Marked differences in disease resistance among accessions were recorded, and this variation in disease reactions was likely due to genetic differences among Capsicum accessions tested.

Despite efforts made in the past decade to evaluate and characterize resistance to $V$. dahliae, the available pool of Verticillium wiltresistant chili pepper appears inadequate, justifying the evaluation of additional sources of resistance to $V$. dahliae for use in Capsicum breeding programs. Previously, C. апnuum accessions PI 555614, PI 555616, and C. baccatum var. microcarpum/C. annuum accession PI 215669 were characterized as resistant to $V$. dahliae in the United States (González-Salán and Bosland 1992), while Woolliams et al. (1962) failed to identify any V. dahliae-resistant Capsicum accessions tested in Canada. This study revealed high levels of resistance to $V$. dahliae in wild and domesticated Capsicum species. Of the 78
Capsicum accessions that we selected and tested in follow up experiments, $21(26.9 \%)$ and $13(16.6 \%)$ were characterized as resistant to $\mathrm{VdCa} 59$ and VdCf45 isolates, respectively, at adult plant stages under greenhouse conditions. Resistance to isolate $\mathrm{VdCa} 59$ was found in C. annuum, C. baccatum, and C. frutescens from Mexico, Costa Rica, and Peru. Similarly, resistance against VdCf45 was found in C. annuum, C. annuum var. glabriusculum, C. baccatum, and C. frutescens from Mexico and Costa Rica. More importantly, eight Capsicum accessions (Grif 9073, PI 281396, PI 281397, PI 438666, PI 439292, PI 439297, PI 555616, and PI 594125) were resistant to both isolates and reisolation of the $V$. dahliae from these resistant pepper plants was unsuccessful. Capsicum annuum accession PI 555616 was also previously reported to have lower disease severity scores (González-Salán and Bosland 1992). However, some of the pepper lines (PI 555614, PI 260550) reported to have lower disease severity were susceptible to both isolates in this study. The stringent criteria (i.e., higher inoculum dose) and inoculation method used in this study may have resulted in discrepancies between the two studies. More interestingly, two of the C. annuum accessions (Grif 9073 and PI 439297), which were resistant to both V. dahliae isolates in this study, were also resistant to Phytophthora root rot when inoculated with multiple isolates of $P$. capsici (Candole et al. 2010). Most of the resistant accessions identified in this study have not been reported previously, and thus represent novel sources of resistance to $V$. dahliae. Thus, pyramiding of resistance genes from these donors could broaden the genetic base of pepper cultivars currently grown commercially, and could serve to control multiple soilborne plant pathogens. In addition, these soilborne, pathogenresistant $C$. annuum accessions may simplify the integration of resistance to several soilborne pathogens.

Resistance to Verticillium wilt in has been hypothesized to be controlled by several genes with minor effects or polygenes (Palloix et al. 1990). However, the plant immune receptor $V e$ was first discovered in the Solanaceous relative tomato (Schaible et al. 1951; Diwan et al. 1999; Kawchuk et al. 2001) and may also exist in peppers, though this currently remains to be elucidated. The $V e$ and its homologs in other plant taxa have played critical roles in developing disease resistance to $V$. dahliae race 1 (Hayes et al. 2007). However, $V e$ and its homologs offer inadequate protection against race 2 isolates because they lack the corresponding avirulence gene, Avel (de Jonge et al. 2012). Notably, deployment of tomato cultivars with the resistance gene $V e$ led to a selective sweep in $V$. dahliae populations, as race 2 isolates now predominate in production fields (Short et al. 2014). Therefore, race is an important consideration when designing experiments to assess Verticillium wilt resistance. Both isolates against which the accessions in this study were screened belonged to race 2 , which predominates California pepper and tomato fields, and the resistance identified as a result is therefore more valuable to the breeding programs.

In summary, we assessed a diverse set of Capsicum accessions from Mexico, the center of origin of peppers, and from other countries, for resistance to multiple isolates of $V$. dahliae and identified eight accessions with notable resistance. Two of the eight were resistant to an additional soilborne pathogen, $P$. capsici, and could be particularly valuable sources of resistance for pepper breeding programs. Since the two resistance sources, Grif 9073 and PI 439297, were identified from domesticated $C$. annuиm accessions, it may be convenient to use them in pepper breeding programs.

\section{Acknowledgments}

The authors thank the excellent technical assistance of Judy Hubbard, Mary Orozco, and Rosa Marchebout during this study and the California Pepper Commission for funding portions of this work. We are also grateful to the USDA Pepper Germplasm Repository for providing the germplasm evaluated in this study.

\section{Literature Cited}

Aguilar-Melendez, A., Morrell, P. L., Roose, M. L., and Kim, S. C. 2009. Genetic diversity and structure in semiwild and domesticated chiles (Capsicum annuum; Solanaceae) from Mexico. Am. J. Bot. 96:1190-1202.

Bhat, R. G., and Subbarao, K. V. 1999. Host range specificity in Verticillium dahliae. Phytopathology 89:1218-1225 
Bhat, R., Smith, R., Koike, S., Wu, B., and Subbarao, K. 2003. Characterization of Verticillium dahliae isolates and wilt epidemics of pepper. Plant Dis. 87: 789-797.

Candole, B. L., Conner, P. J., and Ji, P. 2010. Screening Capsicum annuum accessions for resistance to six isolates of Phytophthora capsici. HortScience 45:254-259.

de Jonge, R., van Esse, H. P., Maruthachalam, K., Bolton, M. D., Santhanam, P., Saber, M. K., Zhang, Z., Usami, T., Lievens, B., Subbarao, K. V., and Thomma, B. 2012. Tomato immune receptor $V e 1$ recognizes effector of multiple fungal pathogens uncovered by genome and RNA sequencing. Proc. Natl. Acad. Sci. USA 109:5110-5115.

Diwan, N., Fluhr, R., Eshed, Y., Zamir, D., and Tanksley, S. D. 1999. Mapping of $V e$ in tomato: A gene conferring resistance to the broad-spectrum pathogen, Verticillium dahliae race 1. Theor. Appl. Genet. 98:315-319.

Douira, A., Ben Kirane, R., Ouazzani Touhami, A., Okeke, B., and Elhaloui, N. 1995. Verticillium wilt of pepper (Capsicum annuum) in Morocco. J. Phytopathol. 143:467-470.

Evans, G., and McKeen, C. 1975. A strain of Verticillium dahliae pathogenic to sweet pepper in southwestern Ontario. Can. J. Plant Sci. 55:857-859.

Fiume, F., Interlandi, G., and Restaino, F. 1982. Evaluation of resistance to Verticillium dahliae Kleb, in lines of Capsicum annuum L. Genetica Agraria. 36:178-189.

García-Mina, J. M., Jordana, R., Aguirreolea, J., and Hernández, M. A. 1996. The effect of a special organic amendment on the development of pepper plants cultivated in a soil infested with Verticillium dahliae. Pages 301-303 in: Fertilizers and Environment. C. Rodriguez-Barreuco, ed. Kluwer Academic, Dordrecht, the Netherlands.

Goicoechea, N. 2006. Verticillium-induced wilt in pepper: Physiological disorders and perspectives for controlling the disease. Plant Pathol. J. 5:258-265.

González-Salán, M., and Bosland, P. 1992. Sources of resistance to Verticillium wilt in Capsicum. Euphytica 59:49-53.

Gurung, S., Short, D. P. G., Atallah, Z. K., and Subbarao, K. V. 2014. Clonal expansion of Verticillium dahliae in lettuce. Phytopathology 104:641-649.

Hayes, R. J., Maruthachalam, K., Vallad, G. E., Klosterman, S. J., and Subbarao, K. V. Selection for resistance to Verticillium wilt caused by race 2 isolates of Verticillium dahliae in accessions of lettuce (Lactuca sativa L.). Hort Science 46:201-206.

Hayes, R. J., Vallad, G. E., Qin, Q.-M., Grube, R. C., and Subbarao, K. V. 2007. Variation for resistance to Verticillium wilt in lettuce (Lactuca sativa L.). Plant Dis. 91:439-445.

Inderbitzin, P., Bostock, R. M., Davis, R. M., Usami, T., Platt, H. W., and Subbarao, K. V. 2011. Phylogenetics and taxonomy of the fungal vascular wilt pathogen Verticillium, with the descriptions of five new species. PLoS One 6:e28341.

Inderbitzin, P., Davis, R. M., Bostock, R. M., and Subbarao, K. V. 2013. Identification and differentiation of Verticillium species and V. longisporum lineages by simplex and multiplex PCR assays. PLoS One 8:e65990.

Kabir, Z., Bhat, R. G., and Subbarao, K. V. 2004. Comparison of media for recovery of Verticillium dahliae from soil. Plant Dis. 88:49-55.

Kawchuk, L. M., Hachey, J., Lynch, D. R., Kulcsar, F., Van Rooijen, G., Waterer, D. R., Robertson, A., Kokko, E., Byers, R., and Howard, R. J. 2001. Tomato Ve disease resistance genes encode cell surface-like receptors. Proc. Natl. Acad. Sci. USA 98:6511-6515.

Maruthachalam, K., Atallah, Z. K., Vallad, G. E., Klosterman, S. J., Hayes, R. J., Davis, R. M., and Subbarao, K. V. 2010. Molecular variation among isolates of Verticillium dahliae and polymerase chain reaction based differentiation of races. Phytopathology 100:1222-1230.
Nicolaï, M., Mélissa, C., Véronique, L., Sage-Palloix, A.-M., and Palloix, A. 2013. Genotyping a large collection of pepper (Capsicum spp.) with SSR loci brings new evidence for the wild origin of cultivated $C$. аnnиum and the structuring of genetic diversity by human selection of cultivar types. Genet. Resour. Crop Evol. 60:2375-2390.

Palloix, A., Pochard, E., Phaly, T., and Daubèze, A. 1990. Recurrent selection for resistance to Verticillium dahliae in pepper. Euphytica 47:79-89.

Pegg, G. F., and Brady, B. L. 2002. Verticillium Wilts. CABI Publishing, New York, NY.

Pernezny, K., Roberts, P. D., Murphy, J. F., and Goldberg, N. P. 2003. Compendium of Pepper Diseases. American Phytopathological Society. APS Press, St. Paul, MN.

Perry, L., Dickau, R., Zarrillo, S., Holst, I., Pearsall, D. M., Piperno, D. R., Berman, M. J., Cooke, R. G., Rademaker, K., and Ranere, A. J. 2007. Starch fossils and the domestication and dispersal of chili peppers (Capsicum spp. L.) in the Americas. Science 315:986-988.

Pesti, M., Tandács, M., and Csölle, I. 1985. Screening and breeding for Verticillium wilt resistance in Capsicum. Capsicum Newsl. 4:64.

Pickersgill, B. 1997. Genetic resources and breeding of Capsicum spp. Euphytica 96:129-133.

Pomar, F., Novo, M., Bernal, M. A., Merino, F., and Barceló, A. R. 2004. Changes in stem lignins (monomer composition and crosslinking) and peroxidase are related with the maintenance of leaf photosynthetic integrity during Verticillium wilt in Capsicum annuum. New Phytol. 163:111-123.

Rekanovic, E., Milijasevic, S., Todorovic, B., and Potocnik, I. 2007. Possibilities of biological and chemical control of Verticillium wilt in pepper. Phytoparasitica 35:436-441.

Rudolph, B. A., and Snyder, W. C. 1937. Verticillium wilt of pepper. Plant Dis. Rep. 21:404.

Sanogo, S., Etarock, B., and Clary, M. 2009. Recovery of Verticillium dahliae from tall morningglory (Ipomoea purpurea) in New Mexico and its pathogenicity on chile pepper. Plant Dis. 93:428

Schaible, L., Cannon, O. S., and Waddoups, V. 1951. Inheritance of resistance to Verticillium wilt in a tomato cross. Phytopathology 41:986-990.

Short, D. P. G., Gurung, S., Maruthachalam, K., Atallah, Z. K., and Subbarao, K. V. 2014. Verticillium dahliae race 2-specific PCR reveals a high frequency of race 2 strains in commercial spinach seed lots and delineates race structure. Phytopathology 104:779-785.

Subbarao, K. V. 2002. Introduction. Phytopathology 92:1334-1336.

Tsror (Lahkim), L., Erlich, O., Amitai, S., and Hazanovsky, M. 1998. Verticillium wilt of paprika caused by a highly virulent isolate of Verticillium dahliae. Plant Dis. 82:437-439

Vallad, G. E., Qin, Q.-M., Grube, R., Hayes, R. J., and Subbarao, K. V. 2006 Characterization of race-specific interactions among isolates of Verticillium dahliae pathogenic on lettuce. Phytopathology 96:1380-1387.

Walsh, B. M., and Hoot, S. B. 2001. Phylogenetic relationships of Capsicum (Solanaceae) using DNA sequences from two noncoding regions: the chloroplast atpB-rbcL spacer region and nuclear waxy introns. Int. J. Plant Sci. 162:1409-1418.

Wilhelm, S. 1955. Longevity of the Verticillium wilt fungus in the laboratory and field. Phytopathology 45:180-181.

Woolliams, G. E., Denby, L. G., and Hanson, A. S. F. 1962. Screening sweet and hot peppers for Verticillium wilt resistance. Can. J. Plant Sci. 42:515-520.

Yanar, Y., and Miller, S. 2003. Resistance of pepper cultivars and accessions of Capsicum spp. to Sclerotinia sclerotiorum. Plant Dis. 87:303-307. 